Азизова В.T., Закариева А.К. Верховный Суд как высший судебный орган по разрешению экономических споров

УДК 347.991

DOI: $10.21779 / 2500-1930-2020-35-2-83-88$

\title{
В.Т. Азизова, А.К. Закариева
}

\section{Верховный Суд как высший судебный орган по разрешению экономических споров}

Дагестанский государственный университет; Россия, 367000, г. Махачкала; ул. М. Гаджиева, 43a; vik_aziz@mail.ru,kaftgp@mail.ru

Актуальность исследованной в статье проблематики обусловлена необходимостью научного осмысления процесса организации и деятельности арбитражных судов, что связано, с одной стороны, с практическими проблемами трансформации судебной ветви власти в целом и функционированием системы арбитражных судов РФ в частности, а с другой - с теоретическими проблемами, связанными с методологическим обеспечением дальнейшего проведения судебно-правовой реформы.

Необходимость определения места Верховного Суда РФ, традиционно являвшегося высшим судом общей юрисдикции, в системе арбитражных судов вызывает ряд споров и дискуссий, поэтому в статье предпринята попытка определить эффективность проведенной реформы с точки зрения результативности деятельности Верховного Суда РФ как высшего судебного органа по разрешению экономических споров. В связи с изменением правового статуса высшего судебного органа государства по разрешению уголовных, гражданских, административных и арбитражных дел произошла и внутренняя реорганизация структуры Верховного Суда РФ, что проявилось в создании дополнительной коллегии - Судебной коллегии по экономическим спорам, деятельность которой проанализирована в данной статье по итогам 2019-2020 гг.

Ключевые слова: арбитражные суды, Верховный Суд РФ, Судебная коллегия по экономическим спорам, эффективность деятельности, судебная реформа.

Главным органом в судебной системе России, на который возложена функция по разрешению споров в экономической сфере, является Верховный Суд РФ. 5 февраля 2014 года были приняты сразу три нормативно-правовых акта, ставшие основой проводимой судебной реформы: Закон РФ о поправке к Конституции РФ «О Верховном Суде Российской Федерации и прокуратуре Российской Федерации» № 2-ФКЗ и федеральные конституционные законы «О Верховном Суде Российской Федерации» № 3-ФКЗ и «О внесении изменений в Федеральный конституционный закон «О судебной системе Российской Федерации»») № 4-ФКЗ.

Следствием таких преобразований стало исключение названия Высшего Арбитражного Суда из всей системы законодательства, было ликвидировано понятие арбитражно-процессуального законодательства (так как все процессуальные отрасли были унифицированы под дефиницией «процессуальное законодательство»). Федеральный конституционный закон «О судебной системе Российской Федерации» закрепил иную систему судов, исключив название Высшего Арбитражного Суда из всей системы законодательства. Был принят Федеральный конституционный закон «О Верховном Суде Российской Федерации», где статус Верховного Суда РФ претерпел серьезные измене- 
Азизова В.T., Закариева А.К. Верховный Суд как высший судебный орган по разрешению экономических споров

ния [2, с. 197]. По сути, в результате внесенных изменений оказались «обезглавленными» две ранее параллельно существующие системы судов - суды общей юрисдикции и арбитражные суды.

Эти изменения неизбежны в связи с тем, что в целом система судов общей юрисдикции не предполагает в своей организации принципа экстерриториальности, т. е. в ней полностью отсутствуют суды, которые не совпадали бы с административнотерриториальным делением РФ, в то время как система арбитражных судов основана исключительно на экстерриториальности [7, с. 22].

Приведенная ситуация иллюстрирует то, что фактически сложилось десять разных подсистем арбитражных судов и 85 подсистем судов общей юрисдикции, причем в целом региональная практика правоприменения по конкретным вопросам даже в рамках одной судебной системы бывает очень различной. Эта практика может разниться даже в рамках судебных составов и коллегий одного суда. В целом наиболее рациональным объяснением сложившейся ситуации представляется социально-экономическая и культурная неоднородность страны, а также значительное влияние на судейское усмотрение ряда субъективных факторов.

Изменения в судебной системе России, особенно среди ее высших органов, ликвидация Высшего Арбитражного Суда привели к проблеме разграничения споров и подсудности дел между судами общей юрисдикции и арбитражными судами [3, c. 10]. И если ранее это были споры о подведомственности дел между этими ветвями судебной власти, то теперь законодатель и правоприменитель сталкивается с проблемой подсудности таких дел практически в рамках одной ветви судебной власти [4, с. 32]. Таким образом, изначальная проблема не устранена, а просто перенесена на другой уровень, и теперь ее разрешение требует больших финансовых вливаний в регулирование данного вопроса в рамках одной судебной системы.

Идея объединения высших судебных инстанций, несомненно, имеет право на существование, но отнюдь не в том виде, в каком это было осуществлено в ходе проводимой судебной реформы. Как представляется, результатом такого объединительного процесса должно было стать формирование еще одной системы специализированных судов (аналогично военным судам) в системе судов общей юрисдикции, однако, как показывает сложившаяся практика, по настоящее время такая ситуация еще не сложилась. Отдельные исследователи считают, что арбитражные суды так и не найдут своего специфического места в системе судов общей юрисдикции, так как они либо полностью ассимилируются с судами общей юрисдикции, либо так и останутся оппозиционно настроенной группой судов с постоянным противостоянием судам общей юрисдикции $[1$, с. 7$]$.

Что касается недавно образованного в системе арбитражных судов Суда по интеллектуальным правам, то он, по нашему мнению, также органично вписался бы в эту систему в качестве специализированного суда общей юрисдикции наряду с арбитражными и военными судами [5, с. 14].

Функции по разрешению экономических споров, ранее подсудных Высшему Арбитражному Суду РФ, осуществляет Судебная коллегия по экономическим спорам Верховного Суда РФ, состоящая из 30 судей.

Предполагается, что данное подразделение Верховного Суда РФ будет второй кассационной инстанцией по делам, связанным с предпринимательской деятельностью. Поступившая в Верховный Суд РФ кассационная жалоба должна быть изучена сначала 
Азизова В.T., Закариева А.К. Верховный Суд как высший судебный орган по разрешению экономических споров

судьей индивидуально и только после такого анализа может быть направлена в данную коллегию.

По аналогии с другими коллегиями Верховного Суда Российской Федерации решения рассматриваемой коллегии могут быть обжалованы в Президиуме данного суда. Надзорная жалоба, как и кассационная, предварительно изучается судьей Верховного Суда РФ и лишь после этого может быть направлена для рассмотрения в Президиум Верховного Суда РФ [6, с. 140].

За 6 месяцев 2020 года Судебной коллегией по экономическим спорам Верховного Суда РФ рассмотрено в кассационной инстанции 17273 жалобы и представления, 191 дело рассмотрено в судебном заседании Судебной коллегии по экономическим спорам; в надзорной инстанции - 252 жалобы, одно дело рассмотрено в судебном заседании Президиума Верховного Суда РФ. Кроме того, 3206 жалоб, включая жалобы, не подлежащие рассмотрению в порядке, установленном процессуальным законодательством, а также жалобы, разрешение которых не относится к компетенции Суда, рассмотрены в Управлении по организационному обеспечению рассмотрения обращений Верховного Суда РФ [8].

За 2019 год Судебной коллегией по экономическим спорам Верховного Суда Российской Федерации рассмотрено:

- в кассационной инстанции: 37015 жалоб и представлений; 482 дела - в судебном заседании Судебной коллегии по экономическим спорам;

- в надзорной инстанции: 306 жалоб, одно дело - в судебном заседании Президиума Верховного Суда Российской Федерации.

Кроме того, 5361 жалоба (4 989 жалоб по делам по экономическим спорам и 372 жалобы по делам об административных правонарушениях), включая жалобы, не подлежащие рассмотрению в порядке, установленном процессуальным законодательством, а также жалобы, разрешение которых не относится к компетенции Суда, рассмотрены консультантами Управления по организационному обеспечению рассмотрения обращений Верховного Суда Российской Федерации [9]. В кассационном порядке в судебном заседании Судебной коллегией рассмотрено 464 дела. По результатам рассмотрения дел в судебном заседании по 11 делам отказано в удовлетворении жалобы, по 453 делам жалобы удовлетворены с отменой или изменением судебных актов. При этом по 198 делам отменены решения судов первой инстанции: 132 решения - с направлением дела на новое рассмотрение, 64 - с принятием нового судебного акта, 1 - с прекращением производства по делу, 1 - с оставлением в силе одного из принятых по делу судебных актов. По 92 делам отменены определения судов первой инстанции: 65 определений - с направлением дела на новое рассмотрение, 25 - с принятием нового судебного акта, 2 - с оставлением в силе одного из принятых по делу судебных актов.

По 259 делам постановления судов апелляционной инстанции отменены одновременно с судебными актами первой инстанции. Всего отменено 333 судебных акта арбитражных апелляционных судов. По 53 делам отменены постановления судов кассационной инстанции с оставлением в силе решения и (или) постановления суда апелляционной инстанции, по 16 делам - с направлением дела на новое кассационное рассмотрение. Отменены 2 определения кассационной инстанции без отмены судебных актов первой и (или) апелляционной инстанций с направлением дел на новое рассмотрение.

Кроме того, отменено 18 определений не по существу спора. Из них 11 определений судов первой инстанции: 7 - с направлением на новое рассмотрение, 3 - с приня- 
Азизова В.T., Закариева А.К. Верховный Суд как высший судебный орган по разрешению экономических споров

тием нового судебного акта, 1 - с оставлением в силе одного из принятых по делу судебных актов; 4 определения судов апелляционной инстанции: 2 - с прекращением производства по делу, 2 - с оставлением в силе одного из принятых по делу судебных актов; 3 определения судов кассационной инстанции: 2 - с направлением на новое рассмотрение, 1 - с оставлением в силе одного из принятых по делу судебных актов [9].

Судебная коллегия по экономическим спорам Верховного Суда РФ:

- в порядке первой инстанции рассматривает дела о признании недействительными (полностью или частично) ненормативных актов Президента РФ, Совета Федерации и Государственной Думы Российской Федерации, Правительства РФ, не соответствующих законодательству;

- рассматривает споры, возникающие из экономических отношений, между федеральным центром и субъектами федерации - по первой инстанции;

- пересматривает принятые этой же коллегией акты, которые вступили в законную силу по вновь открывшимся обстоятельствам;

- рассматривает решения нижестоящих арбитражных судов, которые уже вступили в законную силу в порядке надзорного производства.

К компетенции Судебной коллегии по экономическим спорам Верховного Суда РФ как преемницы Высшего Арбитражного Суда как суда первой инстанции относится разрешение экономических споров между Российской Федерацией и субъектами Федерации, между субъектами Федерации. В качестве суда первой инстанции рассматриваются также дела о признании недействительными и не соответствующими закону и нарушающих права и законные интересы организаций и граждан ненормативных актов Президента РФ, Совета Федерации и Государственной Думы РФ, Правительства РФ. АПК также относит к компетенции Судебной коллегии по экономическим спорам Верховного Суда РФ дела об оспаривании нормативных правовых актов Президента РФ, Правительства РФ, федеральных органов исполнительной власти, затрагивающих права и законные интересы заявителя в сфере предпринимательской и иной экономической деятельности.

\section{Литература}

1. Борисова E.A. Оптимизация устройства судебных инстанций в свете реорганизации судебной системы Российской Федерации // Закон. - 2014. - № 3. - С. 7.

2. Житник Ю.С. Проблемы законодательного закрепления результатов объединения Верховного Суда и Высшего Арбитражного Суда России // Проблемы юридической науки в исследованиях студентов магистратуры. - Ростов н/Д, 2018. - С. 196-199.

3. Карпов Е.Н. Проблемы и перспективы слияния Верховного Суда Российской Федерации и Высшего Арбитражного Суда Российской Федерации // Арбитражный и гражданский процесс. - 2015. - № 3. - С. 9-14.

4. Малько E.A. Объединение Верховного Суда РФ и Высшего Арбитражного Суда РФ: представление через аспекты гражданской процессуальной политики // Судебная система и гражданское общество России. К 150-летию Судебной реформы: материалы международной научно-практической конференции. - 2015. - С. 32-34.

5. Масаладжиу P.M. Новые правила апелляции в арбитражных судах: что разъяснил Верховный Суд // Арбитражная практика для юристов. - 2020. - № 8 (60). - С. $14-23$. 
Азизова B.T., Закариева А.К. Верховный Суд как высший судебный орган по разрешению экономических споров

6. Салеев М.А. Верховный Суд Российской Федерации как последняя инстанция в системе арбитражных судов // Организация государственной и муниципальной власти в России: вопросы теории и практика реализации. - М., 2017. - С. 140-144.

7. Тахтенкова А.О., Грубова Е.И. Правовые последствия объединения Верховного и Высшего Арбитражного судов Российской Федерации // Наука и знание: инновационные подходы к решению практических профессиональных задач по формированию конкурентоспособных специалистов. - Краснодар: Издательство «Краснодарский ЦНТИ», 2014. - С. 22.

8. Обзор статистических данных о рассмотрении в Верховном Суде Российской Федерации в первом полугодии 2020 года административных, гражданских дел, дел по разрешению экономических споров, дел об административных правонарушениях и уголовных дел // Режим доступа: https:/www.vsrf.ru/documents/statistics/29222/ (дата обращения: 01.11.2020).

9. Верховный Суд подвел итоги работы судов за 2019 год // Режим доступа: https:/pravo.ru/story/218428/ (дата обращения: 01.11.2020).

\section{References}

1. Borisova E.A. Optimizaciya ustrojstva sudebnyh instancij v svete reorganizacii sudebnoj sistemy Rossijskoj Federacii // Zakon. 2014. № 3. P. 7.

2. Zhitnik Yu.S. Problemy zakonodatel'nogo zakrepleniya rezul'tatov ob"edineniya Verhovnogo suda i Vysshego Arbitrazhnogo suda Rossii / Problemy yuridicheskoj nauki v issledovaniyah studentov magistratury. Rostov-na-Donu, 2018. P. 196-199.

3. Karpov E.N. Problemy i perspektivy sliyaniya Verhovnogo suda Rossijskoj Federacii i Vysshego Arbitrazhnogo suda Rossijskoj Federacii // Arbitrazhnyj i grazhdanskij process. 2015. № 3. P. 9-14.

4. Mal'ko E.A. Ob'edinenie Verhovnogo suda RF i Vysshego Arbitrazhnogo Suda RF: predstavlenie cherez aspekty grazhdanskoj processual'noj politiki // Sudebnaya sistema i grazhdanskoe obshchestvo Rossii. K 150-letiyu Sudebnoj reformy: Materialy mezhdunarodnoj nauchno-prakticheskoj konferencii. 2015. P. 32-34.

5. Masaladzhiu R.M. Novye pravila apellyacii v arbitrazhnyh sudah: chto raz"yasnil Verhovnyj sud // Arbitrazhnaya praktika dlya yuristov. 2020. № 8 (60). P. 14-23.

6. Saleev M.A. Verhovnyj sud Rossijskoj Federacii kak poslednyaya instanciya v sisteme arbitrazhnyh sudov // Organizaciya gosudarstvennoj i municipal'noj vlasti v Rossii: voprosy teorii i praktika realizacii. M., 2017. P. 140-144.

7. Tahtenkova A.O., Grubova E.I. Pravovye posledstviya ob"edineniya Verhovnogo i Vysshego Arbitrazhnogo Sudov Rossijskoj Federacii // Nauka i znanie: innovacionnye podhody k resheniyu prakticheskih professional'nyh zadach po formirovaniyu konkurentosposobnyh specialistov. - Krasnodar: Izdatel'stvo Krasnodarskij CNTI, 2014. P. 22.

8. Obzor statisticheskih dannyh o rassmotrenii v Verhovnom Sude Rossijskoj Federacii v pervom polugodii 2020 goda administrativnyh, grazhdanskih del, del po razresheniyu ekonomicheskih sporov, del ob administrativnyh pravonarusheniyah i ugolovnyh del // Rezhim dostupa: https://www.vsrf.ru/documents/statistics/29222/ (data obrashcheniya: 01.11.2020)

9. Verhovnyj sud podvel itogi raboty sudov za 2019 god // Rezhim dostupa: https://pravo.ru/story/218428/ (data obrashcheniya: 01.11.2020)

Поступила в редакциюю 10 мая 2020 г. 
UDC 347.991

DOI: $10.21779 / 2500-1930-2020-35-2-83-88$

\title{
Supreme Court as the Highest Judicial Body for the Resolution of Economic Disputes
}

\author{
V.T. Azizova, A.K. Zakarieva \\ Dagestan State University; Russia, 367000, Makhachkala, M. Gadzhiev st., 43a; \\ vik_aziz@mail.ru, kaftgp@mail.ru
}

The relevance of the issues studied in this article is due to the need for scientific understanding of the process of organizing and operating arbitration courts, which is associated, on the one hand, with the practical problems of transforming the judicial branch of government in general and the functioning of the system of arbitration courts of the Russian Federation, in particular, and on the other, with theoretical problems related to methodological support for further judicial reform.

The need to determine the place of the Supreme Court of the Russian Federation, which has traditionally been the highest court of general jurisdiction, in the system of arbitration courts still causes a number of disputes and discussions, therefore, the article attempts to determine the effectiveness of the reform in terms of the effectiveness of the Supreme Court of the Russian Federation as the highest judicial body for resolving economic disputes. In connection with the change in the legal status of the highest judicial body of the state to resolve criminal, civil, administrative and arbitration cases, an internal reorganization of the structure of the Supreme Court of the Russian Federation occurred, which manifested itself in the creation of an additional panel - the Judicial Board for Economic Disputes, the activities of which are analyzed in this article based on the results of 2019-2020.

Keywords: arbitration courts, Supreme Court of the Russian Federation, Judicial Board on economic disputes, efficiency of activity, judicial reform.

Received 10 May, 2020 